\title{
PRELIMINARY ANALYSIS OF THE USE OF SOLID BIOFUELS IN A SHIP'S POWER SYSTEM
}

\author{
Wojciech Zeńczak \\ Agata Krystosik Gromadzińska \\ West Pomeranian University of Technology in Szczecin, Poland
}

\begin{abstract}
This paper presents the results of applying ennobled solid biomass via mechanical compaction or torrefaction as fuel for ships, in terms of fire safety, environmental protection, the increase in liquid fuel prices and the dwindling resources of crude oil. The object of investigation is a ship of the ro-pax ferry type, with low cruising range, which is intended for service on the Baltic Sea. The ship's power system is discussed and the results of calculations of the thermal cycle for a steam turbine power plant are presented. We present a simplified comparative analysis of a fuel bunker for a ship with a power plant including biomass fired boilers, and for a ship with a conventional solution of a motor power plant supplied by ultra-low sulphur fuel originating from crude oil. The advantages of applying a fluidised bed biomass fired boiler are highlighted, and selected results from tests of this boiler are presented. In addition, we assess potential fire hazards on the ship resulting from the storage and transport of pellets, and from pellets after torrefaction.
\end{abstract}

Keywords: ship's power plant,environment protection,biomass,fluidised bed boiler,fire safety

\section{INTRODUCTION}

At present, sea transport is responsible for $2.2 \%$ of the world's emission of $\mathrm{CO}_{2}$, although when $\mathrm{CO}_{2}$ emissions from ships per unit of carried cargo within a distance of $1 \mathrm{~km}$ are taken into account, ships are one of the most efficient means of transport. Despite this, and despite the significant progress that has been achieved in reducing this figure from $2.8 \%$ in 2007 , measures are needed to further reduce $\mathrm{CO}_{2}$ emissions in order to reach the goal of reducing $\mathrm{CO}_{2}$ emissions by $50 \%$ per ton of carried cargo within a distance of $1 \mathrm{~km}$ by 2050 , in comparison with 2005.

It is estimated that the obligation that has been imposed by the International Maritime Organisation (IMO) since 1st January 2013 for all newly built ships (of 400 BRT and higher) that which determines the Energy Efficiency Design Index
(EEDI) will result in a $25-30 \%$ reduction in $\mathrm{CO}_{2}$ emissions by 2030 [1]. Since this date, all ships (including both older ships built before this date and newly built ships of 400 BRT and above) have been required to be covered by the Ship Energy Efficiency Management Plan (SEEMP) to ensure optimal operation [2].

In general, the EEDI is an acceptable standard for controlling environmental pollution from ships, as $\mathrm{CO}_{2}$ emissions are measured in relation to the benefits to society (i.e. work in the form of transport). EEDI is defined as the total $\mathrm{CO}_{2}$ emissions from the main engines, auxiliary engines and boilers as a proportion of transport work. It is possible to achieve a low value by reducing the ship's fuel consumption. For boilers and heat engines, and particularly low-speed engines, the margin for reducing $\mathrm{CO}_{2}$ emission is very small if the fuel consumption is reduced only by increasing the thermal efficiency of the simple thermodynamic cycle. 
The basic actions needed to reduce EEDI therefore include waste heat recovery. The use of renewable energy sources, such as solar energy, wind power and alternative fuels like methanol and natural gas, is also beneficial. The use of LNG or methanol as a fuel decreases $\mathrm{CO}_{2}$ emission, since the conversion factor $C_{F}$, expressed as the ratio of the mass of $\mathrm{CO}_{2}$ resulting from combusted fuel and the fuel mass consumed, is much more favourable than for other marine fuels.

The rate of conversion factor $C_{F}$ depends on the carbon content in the fuel. For marine diesel oil ISO 8217, Grades DMX through DMB, $C_{F}=3.206\left[\mathrm{t}_{\mathrm{CO} 2} / \mathrm{t}_{\text {fuel }}\right]$, and for LNG, $C_{F}=2.75\left[\mathrm{t}_{\mathrm{CO} 2} / \mathrm{t}_{\text {fuel }}\right]$ [3]; in contrast, the value for methanol $\left(\mathrm{CH}_{3} \mathrm{OH}\right)$ is only $\mathrm{C}_{\mathrm{F}}=1.375\left[\mathrm{t}_{\mathrm{CO} 2} / \mathrm{t}_{\text {fuel }}\right]$. LNG and methanol are highly promoted as fuels for ships in the EU due to their low values of $C_{F}$, among other factors. They are also considered important as a way of switching to biofuels. Both LNG and methanol have equivalents among biofuels, i.e. bio methane and bio methanol, which are renewable energy sources and are the gas or liquid forms of biomass.

In addition to $\mathrm{CO}_{2}$ emissions, ships are also responsible for a considerable proportion of sulphur oxide $\left(\mathrm{SO}_{\mathrm{x}}\right)$ and nitrogen oxide $\left(\mathrm{NO}_{\mathrm{x}}\right)$ emissions. It is estimated that the proportion of worldwide total emission of sulphur oxides $\left(\mathrm{SO}_{\mathrm{x}}\right)$ generated by ships is about $5-7 \%$, and for nitrogen oxides $\left(\mathrm{NO}_{\mathrm{x}}\right)$, this figure is $15 \%$ [4]. This means that stricter regulations need to be imposed on the permissible emissions of toxic compounds. The IMO regulations governing this were formulated in Annex VI to the MARPOL 73/78 Convention. The permissible $\mathrm{NO}_{\mathrm{x}}$ emission limits and the dates of their implementations are shown in Table 1.

Tab. 1. MARPOL Annex VI NOx emission limits [5]

\begin{tabular}{|c|l|c|c|c|}
\hline \multirow{2}{*}{ Tier } & \multirow{2}{*}{$\begin{array}{c}\text { Ship construction date } \\
\text { (on or after) }\end{array}$} & \multicolumn{3}{|c|}{$\begin{array}{c}\text { NO limit, g/kWh } \\
\text { (n-engine's rated speed, } \mathrm{min}^{-1} \text { ) }\end{array}$} \\
\cline { 3 - 5 } & \multicolumn{1}{|c|}{$\mathrm{n}<130$} & $130 \leq \mathrm{n}<2000$ & $\mathrm{n} \geq 2000$ \\
\hline I & 1 January 2000 & 17.0 & $45 \cdot \mathrm{n}^{(-0.2)}$ & 9.8 \\
\hline II & 1 January 2011 & 14.4 & $44 \cdot \mathrm{n}^{(-0.23)}$ & 7.7 \\
\hline III & 1 January $2016^{*}$ & 3.4 & $9 \cdot \mathrm{n}^{(-0.2)}$ & 2.0 \\
\hline
\end{tabular}

* In NOx emission control areas (Tier II standards apply outside ECAs)

The Tier III standard limits $\mathrm{NO}_{\mathrm{x}}$ emissions in controlled areas ( $\mathrm{NO}_{x}$ ECAs), whereas Tier II regulations apply outside of these areas. Permissible emissions of sulphur oxides were limited by the introduction of Rule 14 in Annex VI, which regulates the permissible amount of sulphur content in the fuel. These values, both in global terms and within SECA SO Emissions Control Areas, are shown in Table 2.

Tab. 2. Permissible sulphur content in fuel as defined in the MARPOL convention, Annex VI [5]

\begin{tabular}{|l|c|c|}
\hline \multirow{2}{*}{ Date of limit application } & \multicolumn{2}{|c|}{ Sulphur limits in fuel (\%) } \\
& SECA & Global \\
\hline Prior to 1 July 2010 & 1.5 & 4.5 \\
\hline On and after 1 July 2010 & \multirow{2}{*}{1.0} & 3.5 \\
\hline 2012 & & \multirow{2}{*}{0.1} \\
\hline 2015 & \multirow{2}{*}{0.1} & 0.5 \\
\hline 2020 & & \\
\hline
\end{tabular}

Scrubbers to remove sulphur oxides from exhaust gases are permitted both in control areas and globally; ships can therefore use heavy fuel oil (HFO), since sulphur oxide emissions will be reduced to a level equivalent to the required limit. The Baltic and North Seas are within the SECA area, and this creates a particular challenge for ship owners operating in these sea areas.

Another argument in favour of the search for alternative fuels and new solutions for power plants involves crude oil resources that are almost depleted and the growing prices of fuels. These problems have been noted by many authors of scientific papers. Research in this area mostly focuses on more effective waste heat recovery, which allows the efficiency of the ship's power system to be increased and lower $\mathrm{CO}_{2}$ emissions to be obtained.

The high efficiency of modern ship engines (49-51\%) results in a low exhaust gas temperature, meaning that the possibilities of utilising waste heat via the classical Rankine cycle with water as a working medium have therefore reached their limit due to the unacceptably large heat transfer surfaces required in the exhaust gas boiler. Many works have therefore focused on the use of the organic Rankine cycle (ORC) for waste heat recovery; for example, Mondejar et al. present the results of a simulation of an ORC for waste heat recovery on a passenger vessel under different design conditions [6]. Many studies have highlighted various aspects of the use of liquid biofuels in both two-stroke and two-stroke marine diesel engines $[7,8]$.

One solution for reducing emissions may be the use of propulsion systems based on gas turbines (GTs); these require the use of fuels such as marine gas oil (MGO) that are more expensive but have a low sulphur content. Despite the lower efficiency of GTs in comparison with conventional internal combustion engines (ICEs), they are more compact, lighter and their emissions of $\mathrm{NO}_{\mathrm{x}}$ are lower. Armelini presents a comparative analysis of a propulsion system on large cruise ship, with a GT fed with MGO, a classical system with an ICE fed with HFO, and an ICE system fed with HFO and equipped with $\mathrm{De}-\mathrm{NO}_{\mathrm{x}} / \mathrm{De}-\mathrm{SO}_{\mathrm{x}}$ devices. This analysis indicates that the use of GTs as prime movers gives lower weights and volumes and offers environmental benefits. Average annual fuel consumption is higher than for an ICE by $10-20 \%$, depending on the season [9].

Research has also been conducted on the application of various biofuel technologies to marine gas turbines. The authors of [10] analysed the effects of changes in the hydrocarbon composition of fuel for a gas turbine due to the addition of bio-components on the mechanism and intensity of thermal degradation of these fuels. Morsy et al. considered the use of hydrogen or natural gas as alternative fuel to diesel oil for a marine gas turbine [11].

The aim of the present paper is to show that an alternative solution for power plants is the application of solid biomass as fuel, which is a more effective source of renewable energy in comparison with such sources as wind and solar radiation. These sources are characterised by small power density and are temporarily inaccessible. 


\section{SOLID BIOMASS AND ITS REFINEMENT}

Biomass is the organic matter contained in vegetable and animal organisms, which originated as the product of photosynthesis, i.e. the conversion of solar energy into biomass chemical energy. Under the influence of solar radiation, water is decomposed and carbohydrates are generated via a reaction with carbon dioxide:

$$
\mathrm{CO}_{2}+2 \mathrm{H}_{2} \mathrm{O}+h v \rightarrow \mathrm{O}_{2}+\mathrm{H}_{2} \mathrm{O}+\left(\mathrm{CH}_{2} \mathrm{O}\right)+470 \mathrm{~kJ}
$$

where:

$v$ - frequency of electromagnetic radiation,

$h$ - Planck constant [12].

The biomass formed in this way can be considered as a form of solar energy storage. The conversion of biomass chemical energy into heat via the combustion reaction leads to the emission of $\mathrm{CO}_{2}$. This emission can be treated as environmentally friendly, as it is not responsible for the greenhouse effect; the $\mathrm{CO}_{2}$ produced in the reaction is subsequently absorbed by the next generations of plants via photosynthesis, thus forming a closed cycle.

The concept of biomass involves many energy carriers with various properties. Conversion of biomass may take place by gasification or conversion into solid, liquid or gaseous fuels in various processes or simply by direct combustion [13]. Energy technologies for the use of biogenic liquids or gaseous fuels do not differ in principle from those in which petroleum fuels are used; an example of this is combustion engines, including marine engines. The energetic use of solid biomass often has a counterpart in coal-fired power generation technologies.

The dump density of biomass is, however, much lower than that of coal, and the calorific value is lower, meaning that the storage space for biomass is larger in order to achieve the same energy effects. This disadvantage means that biomass is often subjected to a refining process via mechanical compaction, which brings it closer to coal in terms of its bulk density and calorific value. This refined biomass takes the form of pellets or briquettes, which are prepared from dry and shredded biomass such as sawdust, husks, grain, shavings, wood chips and straw. The pellets have a uniform size, an increased energy density and a low moisture content. Depending on the moisture content, biomass is dried or drenched to a water content level of approximately 15\% prior to the pressing and extrusion process. Some forms may require the addition of binders [14].

Another process used to refine biomass is torrefaction, which involves heating the biomass to a temperature of usually between $200^{\circ}$ and $300^{\circ} \mathrm{C}$ in the absence of oxygen, converting it into solid fuel. The properties of this fuel are similar to those of coal. These so-called 'second generation' pellets can also be produced from biomass after torrefaction, and are characterised by an even greater similarity to coal; they also have very good milling sensitivity, which is an important parameter for boilers with dust furnaces [14]. The advantages of torrefied pellets as fuel are highlighted in $[15,16]$, although the problems discussed in these works relate to applications on land.

The calorific value of these pellets is influenced by the raw material used and the torrefaction parameters, such as the temperature and time. The results of the study in [17] show that at the Virginia Mallow plant, carbonisation at $350^{\circ} \mathrm{C}$ for 60 minutes gave a calorific value for the torrefied samples of about $1 \mathrm{MJ} / \mathrm{kg}$ higher than carbonisation at $300^{\circ} \mathrm{C}$ (torrefaction) for the same period.

The increase in the calorific value can also be affected by extending the period of the torrefaction process. The observed increase in the calorific value in both cases is related to a reduction in the moisture content. According to [14], the typical torrefaction increases the energy density of the material by about $30 \%$. Table 3 shows the calorific values and mass and energy densities for various forms of biomass, including conventional and torrefied pellets; for comparison, the same data are given for coal, classical marine fuels and alternative fuels such as LNG and methanol.

Tab. 3. Selected properties of various forms of biomass, coal, marine diesel oil (MDO), heavy fuel oil (HFO) and alternative fuels [14, 17, 18]

\begin{tabular}{|l|c|c|c|}
\hline \multicolumn{1}{|c|}{$\begin{array}{c}\text { Biomass } \\
\text { or other fuel }\end{array}$} & $\begin{array}{c}\text { Calorific } \\
\text { value }[\mathrm{MJ} / \\
\mathrm{kg}]\end{array}$ & $\begin{array}{c}\text { Mass density } \\
{\left[\mathrm{kg} / \mathrm{m}^{3}\right]}\end{array}$ & $\begin{array}{c}\text { Energy } \\
\text { density } \\
{\left[\mathrm{MJ} / \mathrm{m}^{3}\right]}\end{array}$ \\
\hline Grey straw & 15.2 & $90-165$ & $1369-2508$ \\
\hline Timber debarked & 18.5 & $380-640$ & $7030-11840$ \\
\hline Briquetted timber & 17.5 & $470^{1)}$ & 8225 \\
\hline Ordinary timber pellet & 19.5 & $630-750^{1)}$ & $12285-14625$ \\
\hline Torrefied pellets & $23-26$ & $750-850$ & $17250-22100$ \\
\hline LNG & 49 & $431-464^{2)}$ & $21119-22736$ \\
\hline Methanol & 20 & $794\left(\right.$ at $\left.15^{\circ} \mathrm{C}\right)$ & 15880 \\
\hline Marine diesel oil (DMA) & 40 & $890\left(\right.$ at $\left.15^{\circ} \mathrm{C}\right)$ & 35600 \\
\hline Heavy fuel oil (RMK 700) & 39.4 & $1010\left(\right.$ at $\left.15^{\circ} \mathrm{C}\right)$ & 39794 \\
\hline Hard coal & $16-29$ & $800-1000$ & $12800-29000$ \\
\hline
\end{tabular}

1) dump density

2) at boiling point

These parameters have an influence on the fuel stock holder volume for the ship's assumed sailing range.

\section{BIOMASS AS FUEL FOR SHIPS}

\section{CHOICE OF BIOMASS TECHNOLOGY}

When building a ship, it would be most straightforward to replace liquid or gaseous fuels generated from crude oil with their biogenic counterparts, due to the many similarities and knowledge of engine operation gained from using these fuels under shore conditions [19]. Contemporary marine engines are capable of running on biofuels [20], although the use of biomethanol in a self-ignition engine requires the use of a small amount of diesel fuel, which, as in the case of biomethane combustion, results in a partial loss of the benefits of this ecological fuel. The fuel installations themselves must fulfil rigorous requirements, due to their low flashpoint [21]. The use of bio-oils creates fewer problems in 
terms of construction, but the price is high, and is equivalent to the price of ultra-low sulphur diesel oil. In view of this, it is appropriate to consider the use of solid biomass as an alternative fuel in ships. Potential technologies for use in a ship's power plant are shown in Fig. 1.

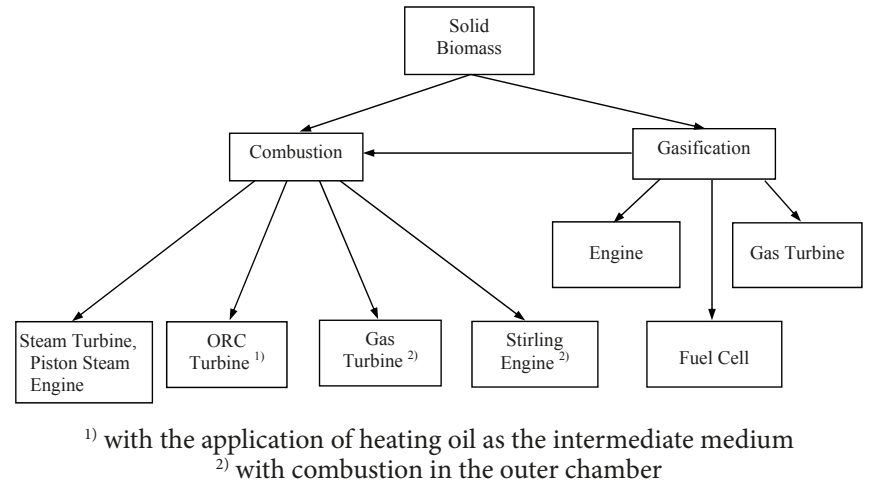

Fig. 1. Technologies that may allow for the use of solid biomass in a ship's power plant [18]

Zenczak noted that 'among the technologies utilizing the direct combustion of biomass, the simplest, tested and suitable for marine conditions is the technology of firing biomass in the boiler and the application of a steam cycle plant' [18]. It was also well proven in marine conditions when the coal was commonly used as fuel. As previously mentioned, refined biomass in the form of torrefied pellets is most similar to carbon in terms of energy density. The volume of stock will therefore be similar to the stock of coal for a ship with the same range. These pellets can also be easily transported from the stock holder to the boiler, for example by the pneumatic method, as used in the last coal-powered ships built in the 1980s, or by means of screw conveyors [22-24].

The emission of $\mathrm{SO}_{x}$ and generation of $\mathrm{NO}_{\mathrm{x}}$ from the nitrogen contained in the pellets is negligible, since the pellets contain less than $0.08 \%$ sulphur and less than $0.3 \%$ nitrogen [13]. For the typical pellets combustion with the air surplus $(\lambda=1.1-1.3)$, the generation of $\mathrm{NO}_{\mathrm{x}}$ mainly takes place in a thermal manner from the nitrogen contained in the air (especially for temperatures exceeding $1300^{\circ} \mathrm{C}$ ). Emissions of $\mathrm{NO}_{\mathrm{x}}$ can be reduced by supplying air gradually for combustion or by using fluidised bed combustion technology, which allows for combustion at lower temperatures [18]. If a fluidised bed boiler is to be used on board a ship, its effectiveness under sea conditions must be tested. The disadvantage of conventional pellets is their hygroscopicity, which leads to the absorption of water from the environment, resulting in swelling and crushing, and special storage conditions are therefore required. These disadvantages do not apply to torrefied pellets, as they have a hydrophobic nature [14].

Due to the storage location of the fuel in this case, i.e. on board a ship, it is very important to conduct tests on the risks associated with stored torrefied pellets and to set safeguards, as there are not sufficiently detailed guidelines from classification societies for solid fuel systems.

\section{FLUIDISED BED BOILER FUELLED BY BIOMASS}

As mentioned above, compared to a boiler with a classic furnace, a fluidised bed boiler ensures environmentally friendly combustion through a reduction in $\mathrm{NO}_{\mathrm{x}}$ and $\mathrm{SO}_{\mathrm{x}}$ emissions. The use of a fluidised bed is also one way of increasing the intensity of the heat exchange process, in which the boiler is characterised by smaller heat exchange surface, thereby improving the overall mass and volume indicators of the ship's power plant.

Since there is a lack of information on the operation of fluidised bed boilers under marine conditions, testing was carried out by the present authors on a physical model. This research involved a model placed on a cradle to simulate the consequences of the impact of a regular sinusoidal wave on a ship. The results of this research were published, inter alia, in [24-27].

The results of investigations of the heat transfer coefficients prove that the heat transfer conditions have a clearly local character that is strongly dependent on the mass of the fluidised bed material located in the column, the flow conditions, the angle of inclination of the fluidised bed column, and the frequency of motion of the cradle. These investigations were conducted on various models of a fluidising column, including a column undergoing cyclical pendulous motion. A diagram of the column during cyclical pendulous motion is shown in Fig. 2.

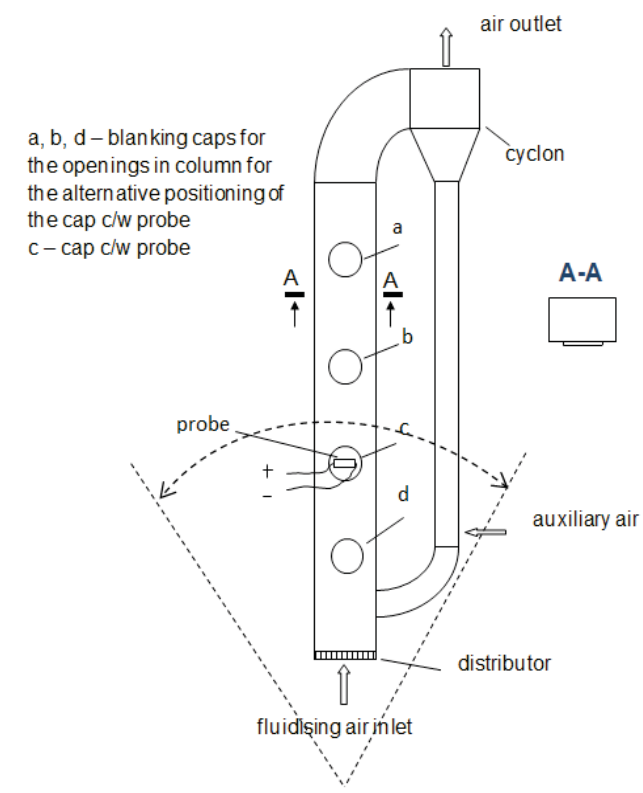

Fig. 2. Diagram of the fluidising column during cyclical pendulous motion, showing the return system for the fluidised bed material

Fig. 3 shows the relationship of the average coefficient of heat transfer between the fluidised bed and the probe surface to the height above the distributor. The fluidising column was kept still, in the vertical position. This relationship indicates a decrease in the average heat transfer coefficient with an increase in the distance of the probe from the air distributor. 
This can be explained by the decrease in the concentration of bed material in the higher parts of the fluidising column.

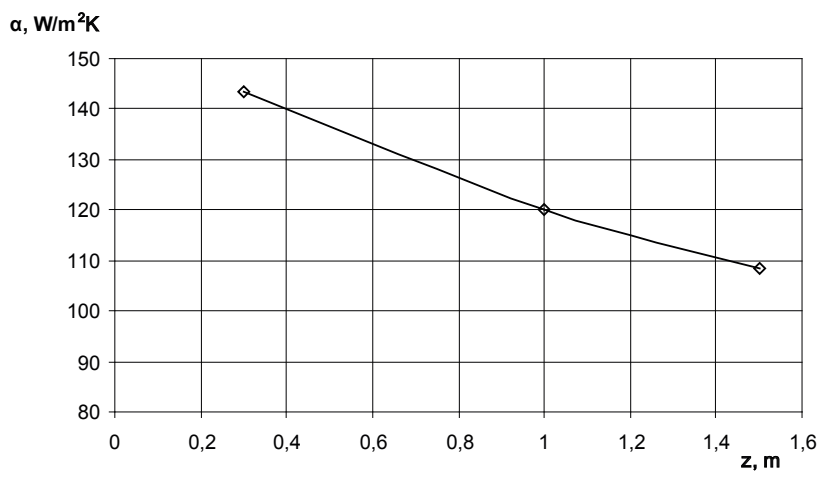

Fig. 3. Relation of the average coefficient of heat transfer between the bubbling bed and the probe surface to the height over the distributor $(z)$ at a constant velocity of the fluidising air $w=6.5 \mathrm{~m} / \mathrm{s}$ and at an immovable vertical position of the column

In all of the experiments on the heat transfer process in the bubbling bed in the column, which was undergoing swinging motion, the value of the heat transfer coefficient was lower during swinging motion than when the column remained still. Within the range investigated here, a shorter period of motion gave a lower heat transfer coefficient. Fig. 4 shows a graph of the values of the heat transfer coefficient in the bubbling bed for a constant RPM of the blower $\left(n=4400 \mathrm{~min}^{-1}\right)$, for a motionless column in the vertical position and for periods of swing of $T=57 \mathrm{~s}$ and $T=34 \mathrm{~s}$ at a $30^{\circ}$ angle of deflection from the vertical. The height of the bed standstill was $H=0.12 \mathrm{~m}$.

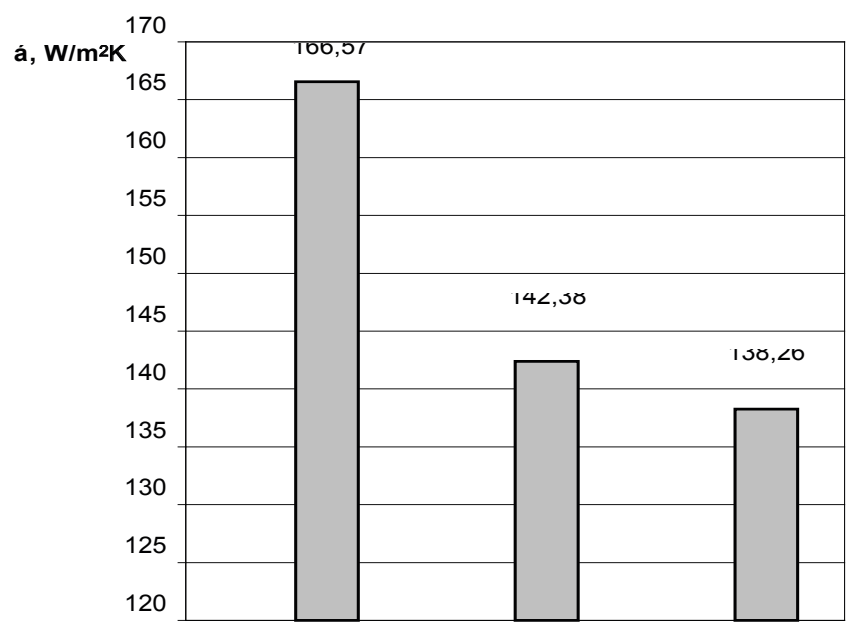

Fig. 4. Average heat transfer coefficient between the bubbling bed and the probe surface, for a constant value of RPM for the blower $\left(n=4400 \mathrm{~min}^{-1}\right)$ during swinging motion of the column with two different periods $(T=57 \mathrm{~s}$, $T=34 s)$ and for an immovable vertical position $(T=\infty)$

The same tendency was observed at smaller values for the RPM of the blower and thus at smaller average velocities of the fluidising air stream; in other words, a decrease in the heat transfer coefficient was seen for shorter swinging periods.

These changes in the value of the heat transfer coefficient between the fluidised bed and the probe surface observed under laboratory conditions will contribute to changes in the capacity of real boilers.

The heat flow rate $\dot{\boldsymbol{Q}}$ transferred to the heat-absorbing surface of the boiler can be determined from the relation:

$$
\dot{Q}=k F \Delta t
$$

where:

$F$ - boiler heating surface,

$\Delta t$ - average temperature difference between the fluidised bed and the working medium (steam/water mixture).

The heat transmission coefficient $k$ for a clean surface is expressed by the formula:

$$
k=\frac{1}{\frac{1}{\alpha_{1}}+\frac{s}{\lambda}+\frac{1}{\alpha_{2}}}
$$

where:

$s-$ thickness of the partition wall,

$\lambda$ - heat conduction coefficient for the partition material, $\alpha_{1}$ - heat transfer coefficient between the fluidised bed and the heat exchanger surface,

$a_{2}$ - heat transfer coefficient between the exchanger surface and the working medium.

It can be assumed that the heat transmission coefficient $k$ is approximately equal to the heat transfer coefficient $\alpha_{1}$ between the bed and the surface, since in Eq. (3) the segments $1 / \alpha_{2}$ and $s / \lambda$, are negligibly small and can be omitted from the technical calculations, i.e.:

$$
k \approx \alpha_{1}
$$

In effect, the assumed heat flow rate will be proportional to $a_{1}$, i.e.:

$$
\dot{Q} \sim \alpha_{1}
$$

Hence, a decrease in the heat transfer coefficient $\alpha_{1}$ for the bubbling bed (e.g. 15\% in the example in Fig. 4) due to the swinging motion of the column (due to the rolling motion of the ship) will influence the heat flow rate and the boiler capacity to a similar degree. 


\section{EVALUATION OF FIRE RISK RESULTING FROM THE USE OF TORREFIED PELLETS AS FUEL ON SHIPS}

\section{Overview}

The risk of fire and explosion generated by classic pellets is connected with their physical and chemical properties, the moisture content and the quantity of pellets. The most common problems connected with the use and transport of pellets are self-heating, self-ignition, explosion (due to dust formation) and oxygen depletion (which poses a risk to personnel). Self-heating may also occur in torrefied pellets, particularly when the pellets are freshly produced (the higher the number of fresh pellets, the higher the risk of self-heating and potential self-ignition) $[28,29]$. Self-heating typically occurs deep inside the bulk, meaning that the source of the fire is difficult to reach and extinguish. An additional problem is a loss of quality along the supply chain, which results in the formation of fine particles and dust. The torrefied pellets are drier and more brittle than conventional ones, which makes them more prone to fire hazard [28].

The parameters that characterise the level of fire risk include the ignition temperature, the self-ignition temperature and, indirectly, the humidity of the biomass.

A knowledge of the following parameters is desirable in order to determine the more specific characteristics: the dust cloud ignition temperature, minimum energy of ignition, lower and upper explosive limits of the dust/air mixture, limiting values of the detonation pressure, dust explosion class, explosion venting factor, maximum explosion pressure [28-32].

Chemical degradation of the pellets starts at a temperature of $40^{\circ} \mathrm{C}$ and biological degradation at $50^{\circ} \mathrm{C}$. Due to poor heat transfer, heat accumulates inside the mass of pellets. Selfheating starts at $80^{\circ} \mathrm{C}$. Factors influencing this temperature are the ambient temperature (which is usually high in engine rooms), moisture content, moisture gradient the bulk volume and density. At temperatures higher than $80^{\circ} \mathrm{C}$, emergency procedures should be started immediately. The pellets should be stored at a temperature of below $45^{\circ} \mathrm{C}$ to ensure an acceptable level of safety $[28,29]$.

Microbiological activities in torrefied pellets are limited. Although the moisture content and the probability of survival of any micro-organisms are very low, the risk of spontaneous ignition is still present; the lower the initial moisture content and the higher the air humidity, the higher the risk of heat generation.

\section{Risk of fire and explosion}

Potential sources of ignition are connected with both the pellets themselves and other factors. The pellets should be clean, since metal pieces or stones could generate sparks capable of ignition. Overheating motors, conveyor belts, bearings (due to high friction), lamps, hot surfaces etc. in the engine room may also increase the risk of explosion, which is connected with the formation of dust. Physical damage is connected with internal operation, improper handling during loading, conveying and transport (over the whole chain). Dust formed from torrefied pellets is more reactive than coal dust, for example [29]. There is a risk of explosion in technological installations related to transportation, disintegration and dust removal, as dust is likely to settle on construction elements.

To minimise dust formation during transport, abrasions, fractures and breakages should be reduced to a minimum. Sharp turns in transport pipes should also be avoided [28]. Care should be taken that even minor amounts of the volatile dust cloud with a concentration approximating the Lower Explosive Limit (LEL) are removed by an aspiration/ventilation system in an explosion-proof setting. During pneumatic transportation in these installations and equipment, the concentration of dust in the air should be kept within the explosive limits. The interiors are therefore explosion risk zones, and automatic devices should be used to prevent explosions and to protect against the accumulation of static electricity charge. Additionally, in the biomass receivers (although this mainly applies to biomass of a loose nature) fixed firefighting equipment should be used that is based on a high-dispersion mist. The role of this mist is not only to extinguish fires but also to prevent the rising of settled dust and the formation of explosive mixtures [33]. This dust is characterised by a very large surface area compared to its mass.

To minimise the risk of self-heating and self-ignition, the pellets should not be stored and transported in large volumes. Furthermore, the mixing of pellets of different types and moisture contents should be avoided. The temperature distribution and emission of gases should also be controlled. The moisture content of the pellets should not be greater than $15 \mathrm{wt} . \%$ [32], and frequent visual inspections are strongly recommended [29].

Pellet storage compartments must be ventilated to remove carbon monoxide and carbon dioxide (chemical oxidation and microbiological processes consume oxygen, and $\mathrm{CO}$ and $\mathrm{CO}_{2}$ are also released). The storage area should be provided with adequate signage and ventilation instructions. A forced ventilation system with a dehumidifier should be utylised to control the amount of moisture injected into the compartment (to avoid a rise in temperature). The fan capacity should not be too low, as an increase in oxygen could result in an increase in temperature rather than a decrease.

Pellets should be stored in free-standing tanks. Piping routes should be within safe places, and the location of any intermediate and terminal tanks should be carefully selected.

Adequate insulation, proper earthing for electric instruments and the provision of a compartment with flame detectors and spray nozzles are also important [33]. The most important factors in minimising the risks of self-heating, spontaneous ignition and explosion are shown in Fig. 5. 


\begin{tabular}{|l|l|l|}
\hline \multicolumn{1}{|c|}{ Minimisation of self-heating, spontaneous ignition } \\
and explosion
\end{tabular}

Fig. 5. Minimisation of self-heating, spontaneous ignition and explosion (based on [29])

Health and safety hazards are associated with the impacts of dust on health (for example the lungs, respiratory system and eyes). Dust can cause allergic reactions and even cancer. Biological hazards are connected with microbiological decay. Fungi produce toxins, e.g. mycotoxins, that can cause allergic reactions. Health hazards are also associated with different volatile organic compounds (VOCs), esters, ethers and aldehydes [28].

\section{Fire extinguishing for pellets}

Fire extinguishing is a difficult problem, since pellets used as fuel in a ship's power plant will be stored in silos. If a fire does occur, the silo should be emptied in the very early stages of the fire, although external oxygen may worsen the fire. An inert gas such as nitrogen or carbon dioxide can be used to extinguish the fire. This must be injected in the gaseous phase, as close as possible to the bottom of the silo. The use of inert gas requires experienced personnel and is expensive $[29,32]$. Water is an alternative, but its use should generally be restricted, except to prevent the formation of dust clouds. Although torrefied pellets do not swell up in the same way as conventional wood pellets, the stability of the ship could be compromised if the quantity of wet pellets is large. A system of compressed air foam is another efficient way of extinguishing a fire in pellets stored in silos [32].

Fire extinguishing is a complicated and time consuming process, and in some scenarios may last several days.

It is important to ensure evacuation of combustion gases from the silo (via the 'check valve' at the top) and to prevent air flows. Emergency discharge should be preceded by inertisation $[28,32]$.

\section{Legislation}

The International Maritime Solid Bulk Cargoes (IMSBC) code is the most important legislation governing the safe carriage of solid bulk cargoes [29].

In accordance with the IMO Report of the Maritime Safety Committee (MSC95/22/Add.2 complement to the IMSBC Code), torrefied pellets can be classified as wood pellets not containing any additives and/or binders. They are in cargo group B class MHB $(\mathrm{OH})$, defined as 'materials hazards only in bulk' and 'other hazards' other than those mentioned in the class division. Pellets pose a low fire risk [34].

Hazards defined by the IMO for pellets are connected with the possibility of oxidation, leading to depletion of oxygen and an increase in carbon monoxide and carbon dioxide in the cargo and communicating spaces, swelling if exposed to moisture, and fermentation over time if the moisture content exceeds $15 \%$, which leads to the generation of asphyxiating and flammable gases, although gas concentrations do not reach flammable levels [34]. In accordance with IMO legislation, pellets are characterised as a cargo with low fire risk. The IMO also highlights the problem of explosion arising from a high dust concentration. The regulations define levels of oxygen $(21 \%)$ and carbon monoxide $(<100 \mathrm{ppm})$ in spaces to be entered by personnel. If necessary, ventilation of enclosed spaces and breathing apparatuses should be provided. In case of fire, the ship's fixed fire-fighting installation should be used, if fitted. Carbon dioxide, foam or water should be used to extinguish the fire [34].

It is therefore possible to identify the risks and prevent dust explosions by following the ATEX regulations and classification of zones with the support of experts .

\section{Proposed recommendations for classification societies}

The use of torrefied pellets in a shipboard engine room requires adequate safety conditions. The pellets must be free from contamination and deliveries from different sources should not be mixed. Torrefied pellets are also particularly susceptible to ignition and self-ignition shortly after production, and hence large amounts of pellets should not be stored. Pellets should be stored in spaces where the temperature will not exceed $45^{\circ} \mathrm{C}$, in free-standing tanks or receivers. Appropriate humidity should be ensured in these compartments so that the pellet humidity is no higher than $15 \%$. In order to remove $\mathrm{CO}_{2}$ and $\mathrm{CO}$ and to supplement $\mathrm{O}_{2}$ (due to depletion), and hence to enable entry by crew members (i.e. oxygen $21 \%$ and carbon monoxide $<100 \mathrm{ppm}$ ), a ventilation system with sufficient capacity should be installed. This system should include a dehumidifier in order to control the amount of moisture injected into the compartment (to prevent a temperature rise). 
The pellets should be transported by means of pipes without abrupt changes in direction and where the dust will not come into contact with sources of ignition with a temperature of over $230^{\circ} \mathrm{C}$. To minimise dust formation during transport, abrasions, fractures and breakages should be kept to a minimum.

Regular inspections of the condition of the pellets should be carried out by crew members. The tanks/receivers should be observed and $\mathrm{CO}$ concentrations measured in the air above the surface of the pellets in order to immediately detect any fire hazard in the tank. The electrical instrumentation should be insulated and provided with appropriate earthing devices. Flame detectors and spray nozzles should be installed in the storage compartment. Inert gases such as nitrogen or carbon dioxide, water or the compressed air foam system should be made available in order to extinguish any fires in the pellets.

The fire safety procedures for a ship's power plant should take into consideration the use of classic and torrefied pellets. The pellets' properties are similar, although the dust from torrefied pellets is more reactive while the probability of self-heating is lower.

\section{CASE STUDY: A POLISH FERRY ON THE ŚWINOUJŚCIE-YSTAD LINE}

\section{BACKGROUND}

An increase in the number of truck transports of 8-10\% per year on the Świnoujście-Ystad line prompted a Polish ship owner to buy a used ferry for this line in Spring 2017 [35]. A decision was also made to build two new ferries in the near future.

The new ship needed to be suitable for the infrastructure of the port in Ystad after a planned expansion. Its parameters were as follows:

- overall length $202.4 \mathrm{~m}$,

- breadth $31 \mathrm{~m}$,

- draught design $6.3 \mathrm{~m}$,

- deadweight $8600 \mathrm{Mg}$,

- total length of car lanes $3000 \mathrm{~m}$,

- number of passengers 399,

- operating speed 18 knots (for 85\% MCR),

- single-screw drive with one dual fuel (MGO low sulphur and LNG), four-stroke, non-reversible engine [36].

The shipowner also considered the construction of a longer unit of $218 \mathrm{~m}$.

At the current stage of the project, the propulsion power, electric power and boiler capacity, which are necessary to determine the fuel stock, have not been disclosed. For the purposes of this study, they were estimated using relations based on statistical surveys of a large population of this category of vessel. Newer relations developed for ferries and ro-ro ships in [37] are as follows:

$$
N_{w}=\left(1.49042+0.0000388 D_{n}\right) v^{3}[\mathrm{~kW}]
$$

$$
\begin{gathered}
N_{e l}=2432+0.14944 N_{w}[\mathrm{~kW}] \\
D_{k \max }=1382+0.115265 N_{w}[\mathrm{~kg} / \mathrm{h}]
\end{gathered}
$$

where:

$N_{w}$ - power of the shaft(s) of main propulsion, $\mathrm{kW}$,

$D_{n}$ - ship's deadweight, $\mathrm{Mg}$,

$v$ - ship's speed, knots,

$N_{e l}$ - electric power, $\mathrm{kW}$,

$D_{k m a \underline{x}}^{e l}-$ capacity of steam boilers, $\mathrm{kg} / \mathrm{h}$.

Based on the ship's parameters, the nominal shaft power was specified as $12,520 \mathrm{~kW}$, the electric power demand was specified as $4,302 \mathrm{~kW}$, and the required boiler capacity was $2,825 \mathrm{~kg} / \mathrm{h}$. An alternative solution for a power plant is proposed in which either classic or torrefied pellets can be used as fuel.

\section{DEVELOPMENT OF THE POWER PLANT SOLUTION}

It was assumed that the alternative solution for a power plant should provide mechanical, electrical and heat energy streams in similar amounts to a motor power plant. It was therefore proposed to replace the diesel engine in the ship's propulsion system with an electric motor. The electricity used to power the main electric propulsion motor and to meet the ship's general needs was produced in power plants consisting of two steam turbogenerators. In this solution, the diesel generator sets were also replaced by steam turbogenerators. Taking into account the power needed for propulsion and the demand for electricity for general purposes, the total power of the power plant was estimated at $17,000 \mathrm{~kW}$. It should be noted that the conversion of diesel engines to steam turbines slightly changes the demand for electricity, which may therefore differ from the value determined from Eq. (7) based on data from motor ships. This is similar to the estimation of steam demand using Eq. (8). The estimated value from Eq. (8) determines the required steam stream for general ship purposes for a motor ship; it is therefore assumed that the required steam stream to the turbogenerators will be added to that for general ship purposes, giving a value of $2000 \mathrm{~kg} / \mathrm{h}$. The steam for the turbogenerators is produced in two fluidised bed boilers, arranged symmetrically on both sides, which are supplied via two pellet holds situated in front of the boilers. The boilers also produce steam for general ship purposes.

This configuration of the power plant should provide good redundancy and reliability, which will result in longer maintenance times per year compared to a diesel engine.

Fig. 6 shows the layout of the pellet storage and transport system, and Fig. 7 shows a simplified diagram of the proposed configuration of the machinery. 


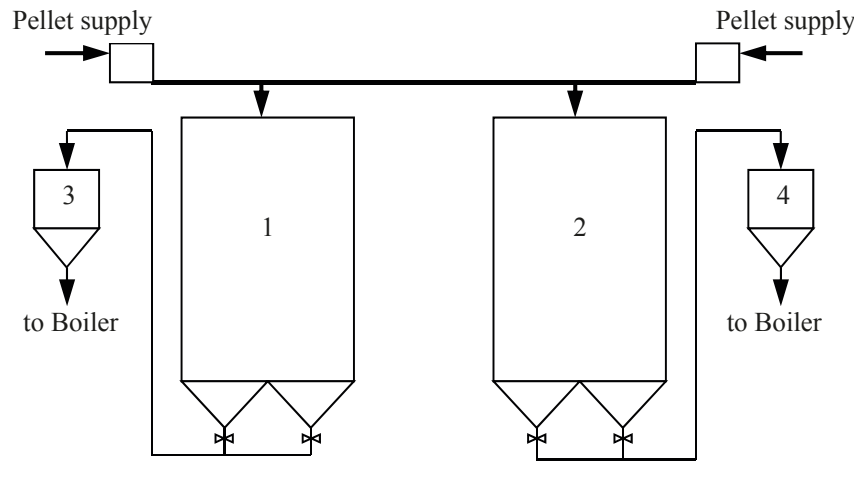

Fig. 6 Layout of the pellet storage and transport system 1,2 - Storage of pellets on starboard and port sides; 3,4 - daily hold of pellets on starboard and port sides

be of a short cruising range. The type of ship analysed here does not have a large cruising range or a large fuel stock since the area of operation is the Baltic Sea. The longest is meridional extension, which is equal to $1300 \mathrm{~km}$. In practice, the ship is designed for a single line, i.e. Świnoujście-Ystad, with a length of only $92 \mathrm{Nm}$, and can sail this distance in less than six hours, at an operating speed of about 17-18 knots. In practice, ferries cross this distance somewhat more slowly, i.e. in about 6-7 hours.

A ferry with steam piston engines and coal-fired boilers was designed for this line in Poland at the end of the 1980s. A 15-hour operating time per day was assumed for the power plant at this speed. The endurance of the ship, which was assumed to be four days, was used to determine the fuel stock rather than the maximum distance to be covered. The coal stock was $440 \mathrm{~m} 3$ and the MDO stock for the port generator set was $123 \mathrm{~m}^{3}$ [38]. A similar endurance is assumed for ferries operating in the Baltic Sea, which are powered by LNG. For example, the largest ferry currently operating on the Turku-Stockholm line, the 'Viking Grace', carries 2,800 passengers and $200 \mathrm{crew}$ members and has two LNG tanks with a capacity of $200 \mathrm{~m}^{3}$ each. This provides three days of operation using LNG for power. An additional five days of operation is provided by the emergency MDO reserve [39]. It should be noted that this route is $175 \mathrm{Nm}$, almost twice as long as the Świnoujście-Ystad route.

For the ferry considered here, the basis for determining the fuel stock in the form of classic pellet or torrefied pellets was an endurance of four days, i.e. the same as for the previously designed ferry with

Fig. 7. Machinery configuration:

1- fluidised bed boiler on starboard side; 2 -fluidised bed boiler on port side; 3,4-turbogenerators; 5,6 - condensers; 7,8 - condensate pumps; 9 - deaerator; 10 - water supply pump.

\section{ESTIMATION OF FUEL STOCK}

A comparison of the energy densities (Table 3) shows that the volume of fuel stock in the form of torrefied pellets is comparable to the volume of stock of coal or LNG for the same cruising range. A comparison with $\mathrm{MDO}$ gives a much poorer result, as this stock needs a volume that is several times smaller than that for pellets. Due to limits on large volumes of fuel stock in the cargo space, the ship should preferably steam piston engines and coal-fired boilers. The same power plant operating time per day at nominal power was assumed, i.e. 15 hours. To determine the stock, it was assumed that the power plant operated on a simple steam cycle. The parameters and the results of the calculations are summarised in Table 4.

Tab. 4. Parameters of the steam turbine power plant cycle

\begin{tabular}{|l|c|c|}
\hline \multicolumn{1}{|c|}{ Parameter } & Value & Unit \\
\hline Steam temperature at the turbine inlet, $t_{1}$ & 530 & ${ }^{\circ} \mathrm{C}$ \\
\hline Steam pressure at the turbine inlet, $p_{1}$ & 9 & $\mathrm{MPa}$ \\
\hline Pressure in the condenser, $p_{c}$ & 0.006 & $\mathrm{MPa}$ \\
\hline Saturated steam pressure, $p_{s}$ & 0.8 & $\mathrm{MPa}$ \\
\hline Steam flux directed for general purposes, $\dot{\boldsymbol{m}}_{\boldsymbol{h}}$ & 0.56 & $\mathrm{~kg} / \mathrm{s}$ \\
\hline Internal turbine efficiency, $\eta_{i}$ & 0.9 & - \\
\hline
\end{tabular}




\begin{tabular}{|l|c|c|}
\hline \multicolumn{1}{|c|}{ Parameter } & Value & Unit \\
\hline Mechanical turbine efficiency, $\eta_{m}$ & 0.97 & - \\
\hline Boiler efficiency, $\eta_{k}$ & 0.85 & - \\
\hline Calorific value of torrefied pellets, $W_{d}$ & 26000 & $\mathrm{~kJ} / \mathrm{kg}$ \\
\hline Calorific value of classic pellets, $W_{d}$ & 19500 & $\mathrm{~kJ} / \mathrm{kg}$ \\
\hline Condensate temperature, $t_{w s}$ & 36 & ${ }^{\circ} \mathrm{C}$ \\
\hline Power of the turbogenerators, $N_{T}$ & 17000 & $\mathrm{~kW}$ \\
\hline
\end{tabular}

The required steam mass flow rate to the power turbine was determined using Eq. (9):

$$
\dot{\boldsymbol{m}}_{T}=\frac{N_{T}}{\Delta i \eta_{m}}
$$

and the consumption of pellets by the boilers $G_{h}$ from Eq. (10):

$$
G_{h}=\frac{\dot{m}_{T}\left(i_{1}-i_{w s}\right)+\dot{m}_{h}\left(i_{s}-i_{w s}\right)}{W_{d} \eta_{k}}
$$

where:

$\Delta i$ - drop in useful steam specific enthalpy in the turbine, $i_{1}$-specific enthalpy of superheated steam at the turbine inlet, $i_{s}$ - specific enthalpy of saturated steam for heating purposes (for $p$ ),

$i_{w s}-$ specific enthalpy of condensate,

- steam mass flow rate for heating purposes.

\section{RESULTS}

The results of the calculations of the steam power cycle and the required fuel stock in the form of classic and torrefied pellets are shown in Table 5. It is estimated that with classic medium-speed diesel engine propulsion powered by ultra-low sulphur fuel (ULSFO), this ferry would use about $220 \mathrm{Mg}$ fuel for 60 hours of operation. Table 6 presents the fuel costs for the assumed 60 hours of operation time of the power plants, based on average prices in July $2020[40,41]$.

A comparison of the costs shows that the fuel costs for a ship with a steam power plant powered by torrefied pellets are slightly higher than the rather low prices for marine fuel. Due to the continuous upward trend in liquid fuel prices in the long run, it can be expected that the pellet supply solution will be more favourable. The current extremely low fuel prices are due to the COVID-19 crisis. Based on bunker prices from January 2020, i.e. before the pandemic, it is more cost-effective to use torrefied pellets for the power plant.

In terms of costs, although the option of using classic pellets gives very similar results to the solution with torrefied pellets, the volume of the classic pellets is larger.

\begin{tabular}{|c|c|c|}
\hline Parameter & Value & Units \\
\hline Steam enthalpy at the turbine inlet, $i_{1}$ & 3548 & $\mathrm{~kJ} / \mathrm{kg}$ \\
\hline Drop in useful steam enthalpy in the turbine, $\Delta_{i}$ & 998 & $\mathrm{~kJ} / \mathrm{kg}$ \\
\hline Condensate enthalpy, $i_{w s}$ & 152 & $\mathrm{~kJ} / \mathrm{kg}$ \\
\hline Saturated steam enthalpy & 2769 & $\mathrm{~kJ} / \mathrm{kg}$ \\
\hline Steam flow directed to the turbines, $\dot{\boldsymbol{m}}_{T}$ & 17.56 & $\mathrm{~kg} / \mathrm{s}$ \\
\hline Total boiler capacity & 18.12 & $\mathrm{~kg} / \mathrm{s}$ \\
\hline $\begin{array}{l}\text { Hourly torrefied pellet consumption for turbine } \\
\text { steam production }\end{array}$ & 9714 & $\mathrm{~kg} / \mathrm{h}$ \\
\hline Total hourly torrefied pellet consumption & 9950 & $\mathrm{~kg} / \mathrm{h}$ \\
\hline $\begin{array}{l}\text { Mass of torrefied pellet stock (for } 60 \mathrm{~h} \text { of power } \\
\text { plant operation) }\end{array}$ & 597 & $\mathrm{Mg}$ \\
\hline $\begin{array}{l}\text { Volume of torrefied pellet stock (for a density } \\
\text { of } 850 \mathrm{~kg} / \mathrm{m}^{3} \text { ) }\end{array}$ & 702 & $\mathrm{~m}^{3}$ \\
\hline Total hourly consumption of classic pellets & 13265 & $\mathrm{~kg} / \mathrm{h}$ \\
\hline $\begin{array}{l}\text { Mass of classic pellet stock (for } 60 \mathrm{~h} \text { of power plant } \\
\text { operation ) }\end{array}$ & 796 & $\mathrm{Mg}$ \\
\hline $\begin{array}{l}\text { Volume of classic pellet stock (for a density } \\
\text { of } 750 \mathrm{~kg} / \mathrm{m}^{3} \text { ) }\end{array}$ & 1061 & $\mathrm{~m}^{3}$ \\
\hline $\begin{array}{l}\text { Mass of MDO stock for diesel engine propulsion } \\
\text { (for } 60 \mathrm{~h} \text { of power plant operation) }\end{array}$ & 220 & $\mathrm{Mg}$ \\
\hline $\begin{array}{l}\text { Volume of MDO stock for diesel engine } \\
\text { propulsion }\end{array}$ & 247 & $\mathrm{~m}^{3}$ \\
\hline
\end{tabular}

Tab. 5. Results of calculations for a steam turbine power plant and fuel stock

Tab. 6. Fuel costs for a steam turbine power plant powered by pellets and a diesel power plant powered by ULSFO for 60 hours of operation time $[40,41]$

\begin{tabular}{|l|c|c|c|}
\hline \multirow{2}{*}{ Parameter } & \multicolumn{3}{c|}{ Fuel type } \\
\cline { 2 - 4 } & $\begin{array}{c}\text { Torrefied } \\
\text { pellets }\end{array}$ & ULSFO & ULSFO \\
\hline Unit price, USD/Mg & 221 & $417^{1)}$ & $600^{1,2)}$ \\
\hline Fuel stock for 60 h operation time, $\mathrm{Mg}$ & 597 & 220 & 220 \\
\hline Fuel cost, USD & 131,937 & 91,740 & 132,000 \\
\hline
\end{tabular}

1) Price is converted from USD/metric ton to USD $/ \mathrm{Mg}$ at a density of $850 \mathrm{~kg} / \mathrm{m}^{3}$

2) Price before the COVID-19 crisis on 24 January 2020

\section{CONCLUSION}

In this paper, we take as an example a ferry intended for shipping in the Baltic Sea region, where strict regulations apply regarding the admissible emissions of toxic compounds, and show that it may be advisable to use a steam turbine power plant with a fluidised bed boiler using classic or torrefied pellets. Model tests demonstrate that the fluidised bed boiler is sensitive to the tilt of the ship, resulting in a decrease in its efficiency, although this was of secondary importance in the cases analysed here. The use of stabilisers on ferries and the relatively low heights of the waves within the Baltic Sea region effectively eliminate this problem.

The potential fire hazards connected with the storage of pellets primarily include self-heating, self-ignition, explosion (due to dust formation) and oxygen depletion (which poses a risk to personnel). The mixing of materials from various supplies should be avoided in order to ensure fire safety in 
regard to the stored pellets. The pellets should also not be stored and transported in large volumes. The amounts of oxygen, oxide and carbon dioxide should be at levels that are safe for the crew, and recommendations for classification societies have been proposed.

A simplified analysis of the operating costs of the ship's power plant also indicates that these can be reduced if the proposed solution is used rather than a diesel power plant. Other positive aspects of the use of biomass as a fuel on ships within a country such as Poland include partial independence from imported petroleum fuels and improvements in the environment through the cultivation of energy crops. However, certain ethical considerations need to be taken into account with respect to the widespread use of biomass for energy purposes, since growing crops for energy should not restrict or compete with food production.

\section{ACKNOWLEDGEMENTS}

This study was partially financed from the means for the project number: No N N509 404536, The National Centre for Research and Development.

\section{REFERENCES}

1. International Chamber of Shipping, 'Shipping World Trade and the Reduction of $\mathrm{CO}_{2}$ Emissions'. [Online]. Available: https://www.ics-shipping.org/docs/defaultsource/resources/environmental-protection/shipsandco2cop21.pdf?sfvrsn=16. [Accessed March 3, 2017].

2. International Maritime Organization, 'Resolution MEPC.213(63) 2012: Guidelines for the Development of a Ship Energy Efficiency Management Plan (SEEMP)', 2017. [Online]. Available: http://www.imo.org/en/ KnowledgeCentre/IndexofIMOResolutions/MarineEnvironment-Protection-Committee-\%28MEPC\%29/ Documents/MEPC.213\%2863\%29.pdf. [Accessed March 3, 2017].

3. International Maritime Organization, 'Resolution MEPC.212(63): Guidelines on the Method of Calculation of the Attained Energy Efficiency Design Index (EDI) for New Ships', 2012. [Online]. Available: http://www.imo.org/ en/KnowledgeCentre/IndexofIMOResolutions/MarineEnvironment-Protection-Committee-\%28MEPC\%29/ Documents/MEPC.212\%2863\%29.pdf. [Accessed March 3, 2012].

4. J.F. Helfre and P.A. Cauto Boot, 'Emission reduction in the shipping: Regulations, exposure and solutions', Sustainalytics, vol. 7, pp. 1-37,2013.

5. International Maritime Organization, 'Resolution MEPC.vol. 176(58) 2010; 1-45. (Revised MARPOL Annex VI)', 2010. [Online]. Available: http://www.imo. org/en/KnowledgeCentre/IndexofIMOResolutions/
Marine-Environment-Protection-Committee-(MEPC)/ Documents/MEPC.176(58).pdf; 2017. [Accessed March 3, 2017].

6. M.E. Mondejar et al., 'Quasi-steady state simulation of an organic Rankine cycle for waste heat recovery in a passenger vessel', Applied Energy, vol. 185, no. 2, pp. 1324-1335, 2017.

7. D. Senatore, Buono, E. Frosina et al., 'Performances and emissions of a 2-stroke diesel engine fueled with biofuel blends', in Proc. of the 69th Conf. of the ItalianThermal-Engineering-Association (ATI), Milan, Italy, 10-13 September 2014, ATI 2014 Book Series: Energy Procedia vol. 81, pp. 918-929, 2015.

8. G. Labeckas, S. Slavinskas, J. Rudnicki, and R. Zadrąg, 'The effect of oxygenated diesel-n-butanol fuel blends on combustion, performance, and exhaust emissions of a turbocharged CRDI diesel engine', Polish Maritime Research, vol. 25, no. 1, 2018, doi:10.2478/pomr-2018-0013.

9. A. Armelini et al., 'Evaluation of gas turbines as alternative energy production system for a large cruise ship to meet new maritime regulations', Applied Energy vol. 211, no. 2, pp. 306-317, 2018.

10. J. Sarnecki, T. Białecki, B. Gawron, J. Głąb, J. Kamiński, A. Kulczycki and K. Romanyk, 'Thermal degradation process of semi-synthetic fuels for gas turbine engines in non-aeronautical applications', Polish Maritime Research , vol. 26, no. 1, Apr. 2019, doi:10.2478/pomr-2019-0008.

11. M. Morsy et al., 'Utilization of alternative marine fuels for gas turbine power plant onboard ships', Int. J. Naval Archit. Ocean Eng., vol. 5, no. 3, pp. 21-32, 2013.

12. W. M. Lewandowski, 'Pro-ecological renewable energy sources' (in Polish), Warszawa: WNT, 2006.

13. T. Chmielniak, 'Energy technologies' (in Polish), Warszawa: WNT, 2008.

14. M. Jakubiak, W. Kordylewski, 'Biomass torrefaction' (in Polish), Archiwum Spalania, vol. 10, no.1-2, pp.11-25, 2010.

15. D. Thrän et al., 'Moving torrefaction towards market introduction - Technical improvements and economicenvironmental assessment along the overall torrefaction supply chain through the SECTOR project', Biomass and Bioenergy, vol. 89, pp. 184-200, 2016.

16. P. McNamee et al., 'An assessment of the torrefaction of North American pine and life cycle greenhouse gas emissions', Energy Conversion and Management, vol. 113, pp. 177-188, 2016. 
17. A. Poskart, S. Szwaja and D. Musiał, 'Virginia mallow char as a fuel for central heating coal boilers' (in Polish), Rynek Energii, vol. 127, no. 6, pp. 104-108, 2016.

18. W. Zeńczak, 'The concept of ship's power plant arrangement involving biomass fired boiler', Journal of Polish CIMAC', vol. 5, no. 1, pp. 205-212, 2010.

19. 'Green Power. Maximum benefit from liquid biofuels', [Online]. Available: http://powerplants.man.eu/docs/ librariesprovider7/brochures/green-power-maxiumumbenefit-from-liquid-biofuel.pdf. [Accessed: May 15, 2016].

20. International Maritime Organization, 'Methanol as marine fuel: Environmental benefits, technology readiness, and economic feasibility. Report No.: 2015-1197, Rev.2', DNVGL, 2016.

21. A. Adamkiewicz and W. Zeńczak, 'Methanol as an ecological fuel for sea-going vessels', in Proc. of the XXIII Energie Symposium. Nutzung regenerativer Energiequellen und Wasserstofftechnik, T. Luschtinetz, J. Lehman, Eds., Stralsund: Fachhochschule, 2016, pp. 170-174.

22. J. T. Schroppe and R. L. Gamble, 'A coal fired fluidizedbed steam generator for marine applications', SNAME Transactions, vol. 89, pp. 379-395, 1981.

23. S. Ikeda, S. Ito, and T. Someya, 'An experimental marine fluidized-bed boiler plant', Marine Engineers Rev., vol. 10, pp. 15-17, 1983.

24. W. Zeńczak, 'Investigation of fluidized bed of the physical model of the marine fluidized bed boiler', Journal of Polish CIMAC, vol. 3, no. 1, pp. 183-190, 2008.

25. W. Zeńczak, 'The research of the influence of the cylindrical heating surface location on the local heat transfer coefficients in fluidised bed of the marine fluidised bed boiler', Journal of Polish CIMAC, vol. 4, no. 1, pp. 161-16, 2009.

26. A. Adamkiewicz and W. Zeńczak, 'Application of the similarity theory in model investigation of a ship's fluidized bed boiler', Scientific Journals of the Maritime University of Szczecin, vol. 23, no. 95, pp. 5-9, 2010.

27. A. Adamkiewicz and W. Zeńczak, 'Method of estimation of heat transfer coefficient between the fluidized bed and the surface immersed in it on an experimental simulation stand of a ship boiler', Scientific Journals of the Maritime University of Szczecin, vol. 21, no. 93, pp. 12-19, 2010.

28. W. Stelle, 'Guidline: storge and handling of wood pellets: Report', Danish Technological Institute, Aarhus, Denmark, 2012. [Online]. Available: https://www.teknologisk.dk/_/
media/52682_RK\%20report\%20storage\%20and\%20 handling\%20of\%20pellets.pdf. [Accessed 17 Sept. 17, 2019].

29. W. Stelle, 'Best practice guideline - Storage and handling of torrified biomass: Report', Danish Technological Institute, Aarhus, Denmark, 2015. [Online]. Available: https://www. teknologisk.dk/_/media/64590_Storage\%20and\%20 Handling\%20of\%20torrefied\%20biomass.pdf. [Accessed Sept. 17, 2019].

30. W. Węgrzyn, 'Explosion hazard in technological processes of transport, storage and combustion of biomass' (in Polish), Prace Naukowe Akademii im. Jana Długosza w Częstochowie. Seria: Edukacja Techniczna $i$ Informatyczna, vol. VI, pp. 9-20, 2011.

31. A. Ickowicz, 'Research on selected properties of torrefiers' (in Polish), Master's thesis, Politechnika Wrocławska, Wrocław , Poland, 2012.

32. K. Jaap, A. Lönnermark, H. Persson, I. Larsson, P. Blomqvist, M. Arshadi et al., 'Health and safety aspects of solid biomass storage. Transportation and feedings: Report', IEA Bioenergy, Enschede, https://www.ieabioenergy.com/ wp-content/uploads/2013/10/Health-and-Safety-Aspectsof-Solid-Biomass-Storage-Transportation-and-Feeding. pdf; 2013. [Accessed Nov. 20, 2019].

33. W. Węgrzyn, 'Fire protection during transport, storage and combustion of biomass' (in Polish), Rynek Instalacyjny, vol. 6, 2009, http://www.rynekinstalacyjny.pl/artykul/ id1003,ochrona-przeciwpozarowa-przy-transporcieskladowaniu-i-spalaniu-biomasy?print $=1$. [Accessed November 3, 2010].

34. International Maritime Organization, 'MSC 95/22/Add. 2., Annex 3., Resolution MSC.393(95), Amendments to the International Maritime Solid Bulk Cargoes (IMSBC) Code', Report of the Maritime Safety Committee on its Ninety-Fifth Session, International Maritime Organization, 2015. [Online]. Available: http://www.syndarma.org.br/ upload/MSC\%2095-22-Add.2\%20-\%20Relat__rio.pdf. 2015. [Accessed March 17, 2016].

35. 'Cracovia - this will be the name of the new ferry in the PŻB fleet' (in Polish), 2017. [Online]. Available: http:// www.gospodarkamorska.pl/Porty,Transport/cracovia--tak-bedzie-nazywal-sie-nowy-prom-we-flocie-pzb.html. [Accessed April 28, 2017].

36. 'What will the new PŻB ferry be like? - the contract was signed, not much is known' (in Polish), 2017. [Online]. Available: http://www.portalmorski.pl/zegluga/promyroro/46828-jaki-bedzie-nowy-prom-pzb-mozliwe-zedowiemy-sie-w-srode. [Accessed April 5, 2017]. 
37. M. Giernalczyk, Z. Górski, Marine power plants, Part I: Fundamentals of propulsion and marine energy (in Polish), Gdynia: Wydawnictwo Akademii Morskiej, 2011.

38. J. Piskorz-Nałęcki, 'Universal ferry for the Świnoujście Ystad line powered by steam piston engines and coal-fired boilers' (in Polish), Budownictwo Okrętowe, vol. 9, pp. 368371, 1987.

39. 'First big ferry fueled by natural gas', HANSA International Maritime Journal, vol. 150, no. 6, pp. 36-43, 2013.

40. 'World bunker prices', 2020. [Online]. Available: https:// shipandbunker.com/prices/. [Accessed July 13, 2020].

41. 'Mig 100 Ltd', 2020. [Online]. Available: https://mig100. co.uk/product/bulk-torrefied-pellets/. [Accessed July 13, 2020].

\section{CONTACT WITH THE AUTHORS}

Wojciech Zeńczak

e-mail: Wojciech.Zenczak@zut.edu.pl

\section{Agata Krystosik Gromadzińska}

e-mail:agata.krystosik@zut.edu.pl

West Pomeranian University of Technology in Szczecin

41 Piastów Ave

PL 71-065 Szczecin,

POLAND 